\title{
Study of Coffee Thread Blight Disease (Corticium koleroga (Cke) Hoehnel) in Ethiopia
}

\author{
Nagassa Dechassa ${ }^{1 *}$, Alemayehu Chala ${ }^{2}$, Kifle Belachew ${ }^{1}$ and Elfinesh Shikur ${ }^{2}$ \\ 1.Ethiopian Institute of Agricultural Research, Jimma Agricultural Research Centre, Jimma, Ethiopia \\ 2.School of Plant and Horticultural Sciences, College of Agriculture, Hawassa University, Hawassa, Ethiopia \\ *Corresponding Author Email: nagookooti@gmail.com
}

\begin{abstract}
Thread blight caused by Corticium koleroga is a devastating disease that causes severe damage to Coffea arabica in Ethiopia. However, it is one of the least researched diseases in Ethiopia. Therefore, the current work was designed with the objectives to (1) assess the intensity of the disease, (2) identify major factors associated with the disease intensity, (3) identify and characterize C. koleroga isolates and (4) determine the pathogenicity of C. koleroga isolates in southwest Ethiopia. For this purpose, field surveys were conducted on 180 farmers' fields in 12 districts of southwest Ethiopia during 2017 cropping season. In addition, diseased samples were collected from 11 districts of southwestern Ethiopia during the study. The $11 \mathrm{C}$. koleroga isolates were characterized using macroscopic and microscopic features. The isolates were cultured on potato dextrose agar and incubated at $25{ }^{\circ} \mathrm{C}$ for ten days. The treatments were arranged in a completely randomized design with three replications. The average thread blight incidence varied from $0 \%$ to $46 \%$ while mean disease severity ranged from $0 \%$ to $44 \%$. The thread blight disease incidence and severity were higher at areas representing highland and midland altitudes compared with lowland altitudes. Thread blight severity was positively and strongly associated with rainfall $(\mathrm{r}=$ $0.75)$ and relative humidity $(\mathrm{r}=0.85)$, but the disease severity was negatively and strongly associated with mean temperature $(r=-0.79)$ and shade level $(r=-0.50)$, while it was positively and intermediately correlated to altitude $(\mathrm{r}=0.44)$ and coffee production systems $(\mathrm{r}=0.36)$. The colony color of $\mathrm{C}$. koleroga isolates were from white to floral white, with circular to irregular form and filiform to entire in margin on PDA plates. Growth rate of the isolates varied between 6 and $9 \mathrm{~mm} /$ day in diameter. Average basidiospore size ranged from 10 to $13.75 \mathrm{x}$ 3.75 to $5 \mu$. All isolates were pathogenic to C. arabica with different lesion sizes. The present study revealed the importance of coffee thread blight, identified factors associated with the disease intensity and morphological characteristics of C. koleroga existing in southwestern Ethiopia. Future research should be directed towards surveying more agro-ecologies to have a complete picture on the importance of thread blight disease across the country and molecular characterization of the pathogen to recommend disease management strategies.
\end{abstract}

Keywords: Basidia; Basidiospore; Disease incidence; Isolates; Koleroga; Mycilium; Severity

DOI: $10.7176 / \mathrm{FSQM} / 113-02$

Publication date: February $28^{\text {th }} 2022$

\section{Introduction}

Coffee (Coffea arabica L.) is the world's most important agricultural cash crop. Next to petroleum, it is the second most valuable traded commodity worldwide. The crop is produced in more than 80 countries including Ethiopia (Musoli et al., 2009). Ethiopia is considered as primary center of origin and diversification for $C$. arabica (Fernie, 1970). The worldwide coffee production in 2017/18 was 9.59 billion $\mathrm{Kg}$, of which about 5.69 billion $\mathrm{Kg}(59.3 \%)$ was $\mathrm{C}$. arabica (FAS, 2018). Ethiopia was ranked as the first largest $C$. arabica producer in Africa and the fourth in the world after Brazil, Colombia and Honduras by producing about $423300.0 \mathrm{Kg}(7.4 \%$ of world production) in 2017/18 cropping season (FAS, 2018).

Though, coffee play significant role in the international economy next to petroleum, the average national productivity has not exceeded $646 \mathrm{Kg} / \mathrm{ha}(\mathrm{CSA}, 2019)$ which is less than half of that achieved in Latin America and Asia. This is partly due to the limited use of improved (technology and varieties) by most small-holder farmers and the wide spread and prevalence of insect pests, diseases and coffee weeds (Girma et al. 2009, Tadesse and Tesfu, 2015, Kifle et al. 2015, Demelash and Ashenafi, 2017, Tamiru et al. 2017). Diseases are the major constraints of coffee production in the country among which are fungal diseases attacking fruits, leaves, stems and roots and reduce the yield and marketability (Girma et al. 2009).

Cavalcante and Sales (2001) reported that CTB disease caused by the phytopathogenic fungi (C. koleroga) is an important disease of Coffee in India, Trindad and Tobego. In Ethiopia the disease had first been recorded in 1978 at Gera and Mettu (Eshetu et al., 2000). CTB diseases on Ethiopian coffee was known for more than 43 years and considered as minor coffee disease. But it is increasingly becoming an important disease and has been observed in wide coffee growing regions of Ethiopia as an epidemic disease in 2014 (Kifle et al., 2015).

Although, CTB disease becomes very important disease in Ethiopia, there is limitation of quantified data that reflect the extent of its distribution and associated factors across different coffee agro ecologies in Ethiopia and the features of the causative pathogen have not yet been characterized in the country. Therefore, this study 
was carried out to assess CTB disease intensity and associated factors at Southwest Ethiopia and morphological characterization of the disease causing pathogen.

\section{Materials and Methods \\ Survey of Coffee Thread Blight \\ Description of the Survey Areas}

During the 2017 rainy season, field surveys were carried out in different coffee growing districts of Ilubabor and Jimma zones in Oromia, and Benchimaji and Sheka zones in SNNPRS. Mettu, Alle and Yayu from Ilubabor; Gera, Gomma and Shebesombo from Jimma; Debubbench, Shako and Gurafarda from Benchimaji; and Yaki, Andaracha and Masha districts from Sheka zones (Figure 1) were selected in order to assess the intensity of thread blight disease. From each of the selected districts, three coffee growing farmers' associations were selected randomly. From each of the selected farmers' associations, five coffee fields were randomly selected at intervals of 10-15 km along the main and accessible rural roads. From each coffee farm, based on the size of the farm, 30-50 trees at 6-8 m interval were used for disease assessment. The age of coffee trees varied from 3 to 30 years. During the survey small scale and large scale farms were considered.

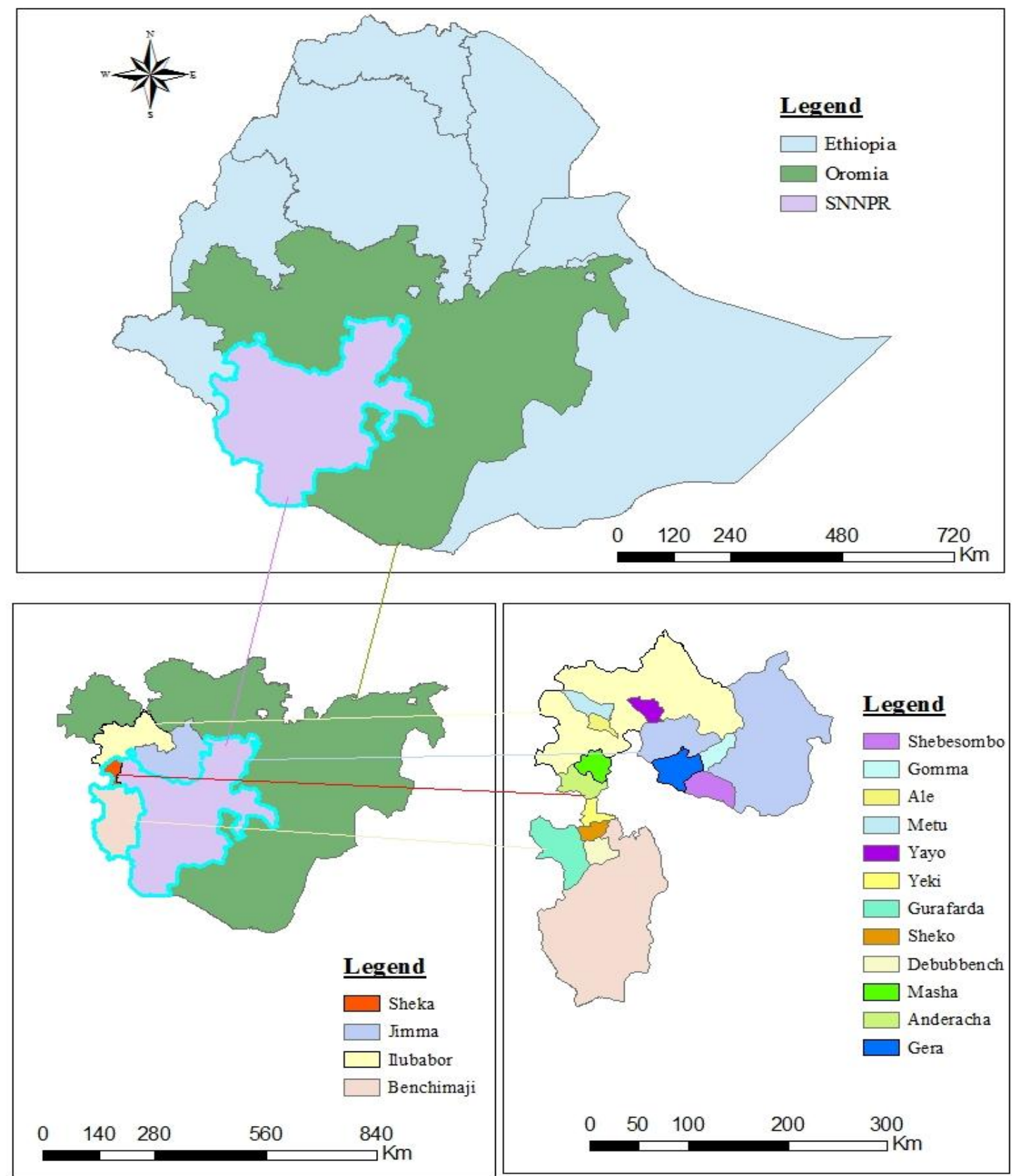

Figure 1. Map of Ethiopia showing regions, zones and districts of Southwest Ethiopia included in the survey program. 


\section{Assessment of Coffee Thread Blight}

Disease assessment was done by visual estimation method per individual sample of coffee tree. In visual estimation method, 30-50 coffee trees were randomly selected in diagonal path from each farm and the number of diseased twigs, leaves and berries were recorded separately and percent of disease incidence and severity were calculated per the mean of plant parts.

Disease Incidence (DI):- The percent of disease incidence was computed for twigs, leaves and berries separately and converted to per plant basis by taking the mean of percent disease incidence of the three plant parts. Percent of disease incidence was computed according to the following equation.

$$
\mathrm{DI}=\frac{\text { Number of infected plant parts (twigs or leaves or berries) }}{\text { Total number of plant parts (twigs or leaves or berries)assessed }} * 100
$$

Disease Severity (DS):- The data regarding the severity of CTB disease was recorded with the slight modification in scale (1-9) devised by Zadoks and Schein (1979) whereas $1=$ no disease, $2=$ disease affecting 1 to $4 \%$ of plant part surface, $3=5$ to $9 \%, 4=10$ to $19 \%, 5=20$ to $29 \%, 6=30$ to $44 \%, 7=45$ to $59 \%, 8=60$ to $75 \%$, and $9 \geq 75 \%$ of plant part surface affected. Disease severity on tree leaves, berries and twigs was also estimated based on percent surface covered by lesions of the disease over total area observed. The percent of disease severity was computed for twigs, leaves and berries separately and converted to per plant basis by taking the mean of disease severity percentage of the three plant parts. This parameter was computed according to the following formula.

$$
\text { Disease Severity }(\%)=\frac{\text { Plant part covered by lesions or rot }}{\text { Total plant part assessed }} * 100
$$

\section{Identification of the Factors Associated with CTB}

Shade types: - Data on shade type were collected at three levels, where coffee farms shaded with more than one tree species were recorded as mixed tree species, while those with only one tree species were recorded as mono tree species and un-shaded farms in open sun were recorded as no-shade (Matovu et al., 2013).

Shade level: - nature of shade at each farm was assessed by visual estimation using a rating scale; No shade (open) $=100 \%$ light penetration, thin (low) shade $=99 \%$ to $70 \%$, Medium shade $=69 \%$ to $40 \%$ and Thick (high) shade $=39 \%$ to $20 \%$ (Matovu et al., 2013).

Varieties: - The kind of planted coffee variety was asked from the growers and the data were recorded.

Coffee yield pattern: - Yield bearing condition of the plant for example biennially or annually was asked from the growers and the data were recorded.

Besides, age of coffee grown in each farm, chemicals and fertilizers used over the past years were recorded during farmers' interview.

Altitude: - Altitude in meters above sea level (m.a.s.l.) was recorded, using Geographic Positioning System (GPS) at a central point for each farm surveyed.

Meteorological data:- such as annual cumulative rainfall, mean temperature and relative humidity of the surveyed areas were obtained from the nearest meteorological stations (Table 1). The monthly weather data (rainfall, temperature and relative humidity) of the surveyed districts were summarized into yearly time scale. The missing daily data were filled by multiple imputation method using XLSTAT statistical software (Schneider, 2001).

\begin{tabular}{|c|c|c|c|c|c|c|}
\hline Study sites & $\begin{array}{l}\text { Altitude } \\
\text { (m.a.s.l) }\end{array}$ & Location & $\begin{array}{l}\text { Annual } \\
\text { rainfall(ml) }\end{array}$ & \multicolumn{2}{|c|}{$\begin{array}{l}\text { Mean temperature ( }{ }^{\circ} \text { ) } \\
\text { (Minimum-maximum) }\end{array}$} & $\begin{array}{l}\text { Relative } \\
\text { Humidity (\%) }\end{array}$ \\
\hline Debubbench & 1192 & $6^{\circ} 95^{\prime} \mathrm{N} 36^{\circ} 00^{\prime} \mathrm{E}$ & 1878.12 & 14.98 & 27.87 & 70.84 \\
\hline Shako & 1150 & $7^{\circ} 04^{\prime} \mathrm{N} 35^{\circ} 25^{\prime} \mathrm{E}$ & 1535.40 & 13.80 & 31.40 & 71.03 \\
\hline Gurafarda & 1259 & $6^{\circ} 52^{\prime} \mathrm{N} 35^{\circ} 18^{\prime} \mathrm{E}$ & 1568.88 & 15.24 & 28.28 & 70.28 \\
\hline Masha & 2282 & $7^{\circ} 75^{\prime} \mathrm{N} 35^{\circ} 47^{\prime} \mathrm{E}$ & 2032.12 & 10.47 & 22.81 & 75.70 \\
\hline Yaki & 1285 & $7^{\circ} 20^{\prime} \mathrm{N} 35^{\circ} 33^{\prime} \mathrm{E}$ & 1491.56 & 15.11 & 29.79 & 69.45 \\
\hline Andarach & 1816 & $7^{\circ} 28^{\prime} \mathrm{N} 35^{\circ} 23^{\prime} \mathrm{E}$ & 1820.21 & 12.10 & 24.00 & 74.25 \\
\hline Mettu & 1550 & $8^{\circ} 30^{\prime} \mathrm{N} 36^{\circ} 00^{\prime} \mathrm{E}$ & 1948.56 & 12.00 & 27.00 & 74.50 \\
\hline Yayu & 1700 & $8^{\circ} 33^{\prime} \mathrm{N} 35^{\circ} 72^{\prime} \mathrm{E}$ & 1664.00 & 13.44 & 28.63 & 69.67 \\
\hline Alle & 2033 & $8^{\circ} 13^{\prime} \mathrm{N} 35^{\circ} 53^{\prime} \mathrm{E}$ & 1811.49 & 14.08 & 24.41 & 75.40 \\
\hline Gera & 1940 & $7^{\circ} 70^{\prime} \mathrm{N} 3600^{\prime} \mathrm{E}$ & 1645.13 & 10.52 & 24.35 & 75.03 \\
\hline Gomma & 1666 & $7^{\circ} 85^{\prime} \mathrm{N} 36^{\circ} 60^{\prime} \mathrm{E}$ & 1521.01 & 11.90 & 28.65 & 72.73 \\
\hline Shebesombo & 1813 & $7^{\circ} 50^{\prime} \mathrm{N} 36^{\circ} 52^{\prime} \mathrm{E}$ & 1558.72 & 14.16 & 26.18 & 70.21 \\
\hline
\end{tabular}

Table 1. Geographic description and average 11 years weather data of districts included in the survey program 


\section{Isolation and Macroscopic and Microscopic Identification \\ Isolation of the pathogen}

Coffee parts exhibiting typical symptoms of thread blight were collected from 11 coffee farms (Table 2). Pathogen isolation was done following standard procedures in Plant Pathology Laboratory at Jimma Agricultural Research Centre (JARC). For isolation of fungal pathogen, the diseased coffee twigs were cut with a sharp sterilized blade into small bits along with some healthy portions. The sections were then surface-sterilized by dipping into $5 \%$ sodium hypochlorite $(\mathrm{NaOCl})$ solution for one minute and rinsed thrice with sterile distilled water (SDW) and finally dried on sterile tissue paper. Then the sections were transferred to potato dextrose agar (PDA) medium in sterilized Petri-plates and incubated at $25{ }^{\circ} \mathrm{C}$ for five days. The isolates were then purified using hyphal tip isolation technique (Zhu et al., 2008).

Table 2. Description of coffee thread blight samples and sample collection from 11 districts of southwestern Ethiopia in 2017 cropping season.

\begin{tabular}{lllll}
\hline Region & Zone & Districts & Kebele (PA) & Altitude (m.a.s.l.) \\
\hline Oromia & Jimma & Shebesombo & Angecha & 1795 \\
Oromia & Jimma & Gera & Sadiloya & 1951 \\
Oromia & Jimma & Gomma & Gembe & 1650 \\
Oromia & Ilubabor & Alle & Segibaki & 1838 \\
Oromia & Ilubabor & Mettu & Geyi & 1555 \\
Oromia & Ilubabor & Didu & Gordomo & 1890 \\
Oromia & Ilubabor & Yayu & Dorani & 1944 \\
SNNPRS & Benchimaji & Shako & Berhanekontir & 1085 \\
SNNPRS & Benchimaji & Debubbench & Abiy-3 & 1550 \\
SNNPRS & Sheka & Andaracha & Duyina & 1816 \\
SNNPRS & Sheka & Masha & Yepho & 1760 \\
\hline
\end{tabular}

SNNPRS: Southern Nations, Nationalities and Peoples' Region.

\section{Macroscopic Identification}

\section{Growth rate of $C$. koleroga isolates}

Mycelial discs ( $5 \mathrm{~mm}$ in diameter) of five day old culture of C. koleroga isolates were transferred to the centre of PDA plates and incubated at $25{ }^{\circ} \mathrm{C}$. Three replications were maintained for each isolate in a completely randomized design (CRD). The colony diameter was recorded at 48 hours interval after incubation. Growth per day was calculated using the following formula:

$\frac{\text { Growth observed on a particular day }(\mathrm{mm})-\text { Growth on previous observation }(\mathrm{mm})}{2}$

The other colony characters, such as form, margin and color were recorded on underside of plate 10 days after incubation.

\section{Microscopic Identification}

Ten days old cultures of all the isolates were characterized by using morphological features. Temporary mounts were studied under compound microscope (Germany) for hyphal (width), basidiospore (width, length) and basidia (shape, color and stages) features. Before measuring the length and width of basidiospores and hyphal diameters, ocular micrometer was calibrated by stage micrometer of compound microscope at 40x objective lens. For each isolate, length and width of 30 randomly taken basidiospores and hyphal width of 30 hyphae per isolate were measured through calibrated ocular micrometer under compound microscope at 40x objective lens. Comparisons of morphological characteristics were made using appropriate information sources or reference laboratory manuals, such as plant pathology guidebooks, global plant protection information system, and the American Phytopathological Society guidelines (Rowhani et al., 2005).

\section{Pathogenicity Test}

Pathogenicity tests of the 11 Corticium koleroga isolates were conducted on the susceptible C. arabica (74110 variety) using the detached twig and leaf methods in air-conditioned growth room. Twigs and leaves were surface-sterilized with $5 \%$ sodium hypochlorite $(\mathrm{NaOCl})$ solution and rinsed twice in sterile distilled water before inoculation.

\section{Inoculum Preparation and Inoculation with Suspension}

Spore suspension was prepared from a seven day old culture of $C$. koleroga isolates by adding $20 \mathrm{~mL}$ of sterile distilled water (SDW) to the Petridish with good colony growth, which was then gently swirled to dislodge the spores. The spore concentration was adjusted to $2 \times 10^{6}$ basidiospores per milliliters using haemocytometer 
(Germany). Sterilized detached coffee leaves and twigs were brushed with C. koleroga inoculum suspension using sterile inoculating brush. The inoculated leaves and twigs were kept in plastic box with dimension WxLxD, $15 \mathrm{~cm}$ x $20 \mathrm{~cm} \times 15 \mathrm{~cm}$ containing moist soft paper and covered with transparent plastic sheet on compartment in air-conditioned growth room. The inside of each box was misted with sterile distilled water using hand sprayer once in an interval of three days. The treatments were arranged in a completely randomized design (CRD) with three replications.

\section{Data Collection}

Data on incubation period were recorded. Data on lesion sizes (in $\mathrm{cm}$ on twigs and \% lesion on leaves) were recorded at 20 days after inoculation. Percentage of infected twigs length was obtained from the lesion length divided by total twig length and multiplied by one hundred (Than et al., 2008). Area of leaf lesions were evaluated using $0-5$, score scales on the typical thread blight lesions developed on the leaves, at 20 days after inoculation. Percent disease severity index (PSI) was calculated as per Wheeler, (1969).

$$
\text { PSI }=\frac{\text { Sum of all numerical ratings }}{\text { Number of leaves observed } * \text { maximum rating }} * 100
$$

\section{Re-isolation of Pathogen}

Then 20 days after inoculation, inoculated twigs and leaves showing active thread blight symptoms were aseptically re-isolated to PDA Petri-plates and incubated at $25{ }^{\circ} \mathrm{C}$ for seven days. The obtained cultures were checked for cultural and morphological characters to confirm the fulfillment for Koch's postulates.

\section{Data Analysis}

Data on disease incidence and severity were analyzed using descriptive statistics. The associations of disease incidence and severity with independent variables such as altitude, production systems, shade level, yield pattern, coffee varieties and meteorological data were analyzed using Pearson correlation and regression using SPSS 20.0 software package (Green and Salkind, 2016). Data of colony growth rate, hyphal diameter, spore dimension (width and length), and lesion size were analyzed using analysis of variance (ANOVA) with least significant difference (LSD) at 5\% probability level by using SAS Software Version 9.3 (SAS, 2011).

\section{Results}

\section{Coffee Thread Blight Intensity across Southwest Parts of Ethiopia}

Thread blight intensity among the surveyed administrative districts of the Southwest part of Ethiopia was also highly variable. At district level, the disease severity ranged between 0 to $44.04 \%$. The highest mean CTB disease incidence $(45.86 \%)$ and severity $(44.04 \%)$ were recorded in Masha district followed by Mettu, Andaracha, Alle, Gera and Gomma in that order. On the other hand, the disease was absent $(0 \%$ incidence $)$ in Debubbench, Yaki and Gurafarda districts (Table 3).

Table 3. Incidence and severity of thread blight at districts of southwest Ethiopia in 2017

\begin{tabular}{llllll}
\hline Zone & District & $\begin{array}{l}\text { No. of farms } \\
\text { surveyed }\end{array}$ & $\begin{array}{l}\text { Altitude } \\
\text { (m.a.s.l.) }\end{array}$ & Incidence (\%) & Severity (\%) \\
\hline Sheka & Masha & 15 & $1550-2010$ & 45.86 & 44.04 \\
Ilubabor & Mettu & 15 & $1550-1974$ & 42.65 & 40.04 \\
Sheka & Andaracha & 15 & $1220-1830$ & 27.53 & 22.26 \\
Ilubabor & Alle & 15 & $1350-1838$ & 25.55 & 22.56 \\
Jimma & Gera & 15 & $1616-1989$ & 21.05 & 19.04 \\
Jimma & Gomma & 15 & $1550-1675$ & 19.23 & 17.33 \\
Ilubabor & Yayu & 15 & $1420-1969$ & 13.85 & 12.32 \\
Benchimaji & Shako & 15 & $1072-1724$ & 2.70 & 2.58 \\
Jimma & Shebesombo & 15 & $1550-1795$ & 1.28 & 1.14 \\
Benchimaji & Gurafarda & 15 & $1070-1414$ & 0 & 0 \\
Benchimaji & Debubbench & 15 & $985-1293$ & 0 & 0 \\
Sheka & Yaki & 15 & $1189-1260$ & 0 & 0 \\
\hline
\end{tabular}

\section{Factors Affecting Thread Blight Disease}

\section{Shade Levels}

There was highly significant $(p<0.01)$ and negative correlation between shade level on one hand and CTB disease incidence and severity $(r=-0.51)$ on the other (Table 4$)$. The disease became more intense as shade level decreases. Accordingly, the highest mean disease incidence $(64.08 \%)$ and severity $(57.28 \%)$ were recorded under full sun light (open) growing conditions. Low, medium and high shade levels had CTB incidence and 
severity of 37.58 and $32.63 \%, 6.73$ and $6.44 \%$, and 4.65 and $4.19 \%$, respectively. This pattern could have resulted from the following reasons: a) shade tree prevents fruit loads (optimizes fruits to leaves ratio) (Staver et al. 2001; Ratnadass et al. 2011), b) it modifies microclimate conditions (Staver et al. 2001; Ratnadass et al. 2011) c) it serves as habitat for a large number of species which are directly involved in pest and disease bio-control (Soto-Pinto et al., 2001), d) it limits the splash dispersal of propagules which serve as inoculum (Mouen-Bedimo et al., 2008).

Table 4. Pearson correlation coefficients between disease intensity and associated factors

\begin{tabular}{llllllll}
\hline & DI & DS & SL & ST & Alt & PS & YP \\
\hline DI & & & & & & & \\
DS & $0.99^{* *}$ & & & & & & \\
SL & $-0.51^{* *}$ & $-0.51^{* *}$ & & & & & \\
ST & $-0.49^{* *}$ & $-0.48^{* *}$ & $0.66^{* *}$ & & & & \\
Alt & $0.43^{* *}$ & $0.44^{* *}$ & $-0.21^{* *}$ & $-0.23^{* *}$ & & & \\
PS & $0.39^{*}$ & $0.36^{*}$ & $0.05^{\text {ns }}$ & $-0.05^{\text {ns }}$ & -0.12 & & \\
YP & $-0.45^{* *}$ & $-0.43^{* *}$ & $-0.03^{\text {ns }}$ & $0.04^{\text {ns }}$ & $0.09^{\text {ns }}$ & $-0.78^{* *}$ & \\
Variety & $-0.03^{\text {ns }}$ & $-0.03^{\text {ns }}$ & $-0.24^{* *}$ & $-0.13^{\text {ns }}$ & $-0.16^{*}$ & $-0.01^{\text {ns }}$ & $-0.003^{\text {ns }}$ \\
\hline
\end{tabular}

$\mathrm{DI}=$ Disease Incidence, $\mathrm{DS}=$ Disease severity, $\mathrm{SL}=$ Shade Level, $\mathrm{ST}=$ Shade Type, Alt $=$ Altitude, PS $=$ Production system, YP $=$ Yield Pattern, $*=$ correlation is significant at $\mathrm{p} \leq 0.05 * *=$ correlation is significant at $\mathrm{p}<0.01,{ }^{\mathrm{ns}}=$ correlation is insignificant at $\mathrm{p} \leq 0.05$.

\title{
Shade Type
}

In this study, there was highly significant difference $(p<0.01)$ and negative intermediate correlation between shade type and CTB disease incidence $(r=-0.49)$ and severity $(r=-0.48)$ (Table 4$)$. The disease became more intense under no shade followed by mono-shade, whereas low disease incidence and severity were recorded under mixed shade types. Correspondingly higher average disease incidence $(41.56 \%)$ and severity $(37.34 \%)$ were recorded under un-shaded farms followed by farms with single tree species $(13.42 \%$ and $12.58 \%)$ and the lowest (12.67\% and $11.77 \%$ ) diseases incidence and severity, respectively, in farms with mixed tree species.

\section{Coffee Production Systems}

There was significant $(p<0.05)$ and positive intermediate correlation between coffee production systems and CTB disease incidence $(r=0.39)$ and severity $(r=0.36)$ (Table 4). The disease became more intense in plantation followed by garden, semi forest and forest coffee production systems. The occurrence of CTB is higher in plantations and gardens with poor cultural practices, especially, when the normal rounds of pruning unnecessary twigs are not practiced and optimum shade is not provided. The probable reason for the variation in intensity of the disease among the different production systems could be the effect of human interference.

\section{Coffee Yield Pattern and Variety}

There was highly significant $(p<0.01)$ and negative intermediate correlation between coffee yield pattern and CTB disease incidence $(r=-0.45)$ and severity $(r=-0.43)$ (Table 4). Higher mean disease incidence of $21.70 \%$ and severity of $19.87 \%$ were recorded in the annual than in the biennial coffee. There was negative weak correlation between coffee varieties and CTB disease incidence $(r=-0.02)$ and severity $(r=-0.03)$ (Table 4). The disease became more intense (mean incidence of $17.47 \%$ and severity of $16.27 \%$ ) on local varieties than on improved varieties.

\begin{abstract}
Altitude
Altitude is also one of the factors positively associated with CTB disease. There was a positive intermediate correlation between altitude and incidence $(r=0.43)$ and severity $(r=0.44)$ of CTB disease (Table 4). The highest mean disease incidence $(28.09 \%)$ and severity $(25.70 \%)$ across altitude gradients were recorded at highland coffee producing areas, whereas percent of disease incidence and severity were very low at lowland areas with mean disease incidence of $4.04 \%$ and severity of $3.69 \%$. As in the cases of districts such as Masha, Mettu, Andaracha, Alle, Gera, Gomma and Yayu, which are located in medium to higher altitude ( $>1500$ m.a.s.1), the percent of disease incidence and severity increased with increasing altitudes. This might be because of prolonged rainfall and storms accompanied by hail in the highland areas like Mettu and Masha.
\end{abstract}

\section{Meteorological Factors}

Thread blight incidence and severity had highly significant $(\mathrm{p}<0.01)$ correlations with cumulative rainfall $(\mathrm{r}=$ 
0.74 and $\mathrm{r}=0.75$, respectively), relative humidity $(\mathrm{r}=0.86$ and $\mathrm{r}=0.85$, respectively) and mean temperature $(\mathrm{r}=$ -0.81 and $\mathrm{r}=-0.79$, respectively) (Table 5).

Table 5. Pearson correlation coefficients between disease intensity and meteorological factors

\begin{tabular}{lllll}
\hline & Incidence & Severity & Rainfall & Relative Humidity \\
\hline Incidence & & & & \\
Severity & $0.99^{* *}$ & & & \\
Rainfall & $0.74^{* *}$ & $0.75^{* *}$ & & \\
Relative Humidity & $0.86^{* *}$ & $0.85^{* *}$ & $0.67^{*}$ & \\
Temperature & $-0.81^{* *}$ & $-0.79^{* *}$ & $-0.62^{*}$ & $-0.86^{* *}$ \\
\hline
\end{tabular}

$*=$ Significant at $\mathrm{p}<0.05, * *=$ Significant at $\mathrm{p}<0.01$.

The result of this research indicated that the decreased level of rainfall and relative humidity may lead to decreased incidence and severity of thread blight disease on $C$. arabica. Whereas the periods of high and prolonged rainfall and high relative humidity, which result in prolonged periods of plant parts wetness, are the most important meteorological factors influencing the occurrence and further development of CTB disease in the field.

\section{Morphological Characterization of the Pathogen Symptomatological Identification}

In the field, thread blight disease on C. arabica appeared as thread-like white to ashen strand on the middle stem of the coffee tree at first (Figure $2 \mathrm{~A}$ ) and then the black plus whitish strands of nodes, internodes of the twigs (Figure $2 \mathrm{~B}$ ). The blackening of leaf petiole later spread to leaf blade predominantly on the lower surfaces of leaves. The strands always branch off from the leaf petioles to leaves and then spread out into numerous fine ones. The fine strands initiated dark-ashen necrosis and as the whole leaf became involved, the leaf separated at the petiole but usually remained hanging from mycelial strand that grew over the petiole from the branch (Figure $2 \mathrm{C}$ ). On berries, the sunken black with ashen myceilial strands were seen as necrotic symptoms of the disease (Figure $2 \mathrm{D}$ ).
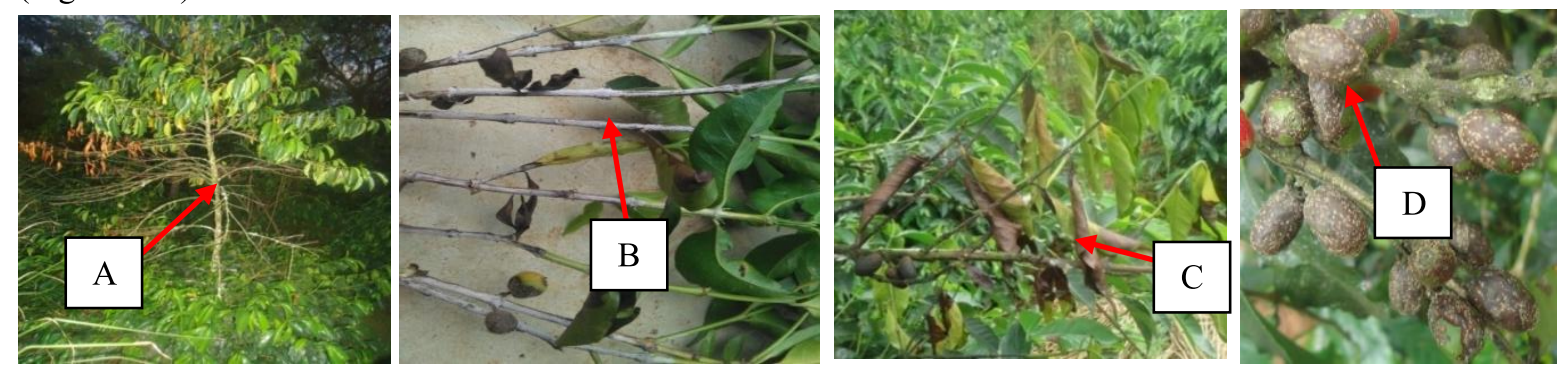

Figure 2. Thread blight on Coffea arabica was seen as thread-like white to ashen strand on A) Middle stem, B) Branch, C) Leaf and D) Berries observed at Mettu, in 2017 cropping season.

\section{Macroscopic and Microscopic Identification \\ Macroscopic Identification \\ Growth Rate of Mycilia}

The study revealed considerable colony growth rate variations among C. koleroga isolates collected from different coffee producing regions of Ethiopia. Isolates differed highly and significantly ( $\mathrm{p} \leq 0.01)$ in growth rate in diameter ranging between 6 and $9 \mathrm{~mm} \mathrm{day}^{-1}$, with a mean of $8.02 \mathrm{~mm}^{-1} \mathrm{day}^{-1}$ in diameter (Table 6). Isolates from midland areas had the fastest $\left(8.55 \mathrm{~mm} \mathrm{day}^{-1}\right.$ on average) growth rate, while isolates from highland areas grew slowly (mean growth rate of $7.09 \mathrm{~mm} \mathrm{day}^{-1}$ in diameter). Isolates of C. koleroga collected from Andaracha, Shebesombo, Mettu and Shako grew the fastest $\left(8.5\right.$ to $\left.9 \mathrm{~mm} \mathrm{day}^{-1}\right)$, followed by isolates from Yayu, Didu and Masha, which grew at 8.1 to $8.4 \mathrm{~mm} \mathrm{day}^{-1}$. Isolates from Agaro, Debubbench, Gera and Alle had slow (6.40 to $7.50 \mathrm{~mm} \mathrm{day}^{-1}$ ) growth rate in diameter. In the present study, C. koleroga isolates showed periodic changes in their growth rates. Generally all the isolates showed an increasing trend in growth rate from 2 days onward up to 8 days but growth rate decreased or declined afterwards.

\section{Colony Color, Elevation and Margin}

Colony color, form, elevation and margin did not differ very much among the tested isolates of C. koleroga on PDA medium (Table 7; Figure 3). The C. koleroga isolates produced mycelia with white to floral white front and back side color, filiform to entire margins and irregular to circular in form and produced in abundance. Front side colony color of almost all isolates in the culture were white except isolates form Gera, which seems floral 
white and the back side colony color of Alle, Andaracha, Gera, Masha, Mettu, Shako and Yayu isolates were floral white. On the other hand, Agaro, Didu, Debubbench and Shebesombo isolates seemed to have white back side colony color. Colony elevations of all isolates were flat. The colony margins of all the isolates were entire, except that of Shako and Masha isolates that had filiform colony margin.

Table 6. Colony growth rate, hyphal width, spore width and length of C. koleroga isolates of southwestern Ethiopia in 2017 cropping season

\begin{tabular}{|c|c|c|c|c|c|c|c|}
\hline \multirow{2}{*}{ Isolates } & \multirow{2}{*}{$\begin{array}{l}\text { GR } \\
(\mathrm{mm})\end{array}$} & \multicolumn{2}{|l|}{ HT $(\mu)$} & \multicolumn{2}{|c|}{$\mathbf{S W}(\mu)$} & \multicolumn{2}{|l|}{ SL $(\mu)$} \\
\hline & & Range & Average & Range & Average & Range & Average \\
\hline Andarach & $9.00^{\mathrm{a}}$ & $3.75-5$ & 4.84 & $3.75-5$ & 4.84 & $11.25-13.75$ & $12.71^{\mathrm{ab}}$ \\
\hline Shebesombo & $8.97^{\mathrm{a}}$ & $3.75-5$ & 4.84 & $3.75-5$ & 4.84 & $11.25-13.75$ & $12.65^{\mathrm{ab}}$ \\
\hline Mettu & $8.80^{\mathrm{a}}$ & $3.75-5$ & 4.79 & $3.75-5$ & 4.88 & $12.50-13.75$ & $12.58^{\mathrm{ab}}$ \\
\hline Shako & $8.50^{\mathrm{b}}$ & $3.75-5$ & 4.88 & $3.75-5$ & 4.79 & $12.50-13.75$ & $12.83^{\mathrm{a}}$ \\
\hline Yayu & $8.40^{b c}$ & $3.75-5$ & 4.84 & $3.75-5$ & 4.75 & $10.00-12.50$ & $11.75^{\mathrm{cd}}$ \\
\hline Didu & $8.13^{b c}$ & $3.75-5$ & 4.96 & $3.75-5$ & 4.96 & $10.00-12.50$ & $11.67^{\mathrm{d}}$ \\
\hline Masha & $8.10^{\mathrm{d}}$ & $3.75-5$ & 4.84 & $3.75-5$ & 4.84 & $12.50-13.75$ & $12.62^{\mathrm{ab}}$ \\
\hline Agaro & $7.50^{\mathrm{e}}$ & $3.75-5$ & 4.84 & $3.75-5$ & 4.92 & $10.00-12.50$ & $12.55^{\mathrm{b}}$ \\
\hline Debubbench & $7.43^{\mathrm{e}}$ & $3.75-5$ & 4.92 & $3.75-5$ & 4.96 & $10.00-12.50$ & $11.75^{\mathrm{cd}}$ \\
\hline Gera & $6.73^{f}$ & $3.75-5$ & 4.79 & $3.75-5$ & 4.79 & $10.00-12.75$ & $12.67^{\mathrm{ab}}$ \\
\hline Alle & $6.46^{\mathrm{f}}$ & $3.75-5$ & 4.84 & $3.75-5$ & 4.88 & $10.00-12.25$ & $12.00^{\mathrm{c}}$ \\
\hline CV (\%) & 2.04 & & 1.74 & & 2.20 & & 1.23 \\
\hline LSD (0.05) & 0.28 & & 0.12 & & 0.18 & & 0.26 \\
\hline
\end{tabular}

$\mathrm{GR}=$ Colony growth rate in diameter per day, HT = Hyphal thickness, SW = Spore Width, SL = Spore Length, Means in a column followed by the same letter are not significantly different at $\mathrm{p}<0.05$.

Table 7. Cultural characteristics of Corticium koleroga isolates on Potato Dextrose Agar (PDA) at 10 days incubation

\begin{tabular}{lllllll}
\hline Isolates & Colony color & & & \multicolumn{2}{c}{ Colony } \\
\cline { 2 - 3 } \cline { 5 - 6 } & Front & Back & & Form & Elevation & Margin \\
\hline Mettu & White & Flora white & & Circular & Flat & Entire \\
Yayu & White & Floral white & & Circular & Flat & Entire \\
Gera & White & Floral white & & Circular & Flat & Entire \\
Agaro & Floral white & Floral white & & Circular & Flat & Entire \\
Andaracha & White & Floral white & & Circular & Flat & Entire \\
Masha & White & Floral white & & Circular & Flat & Entire \\
Shako & White & Floral white & & Irregular & Flat & Filiform \\
Debubbench & White & Floral white & & Irregular & Flat & Filiform \\
Shebesombo & White & White & & Circular & Flat & Entire \\
Didu & White & White & & Circular & Flat & Entire \\
\hline
\end{tabular}



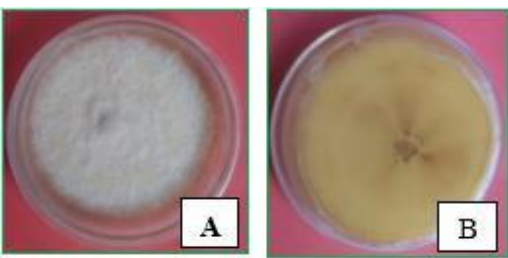

Yayu isolate

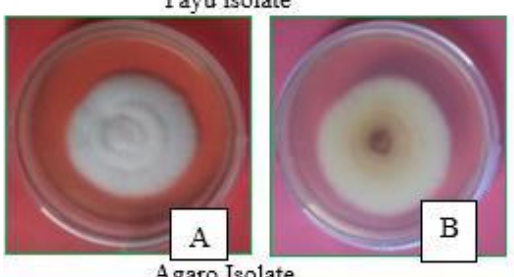

Agaro Isolate

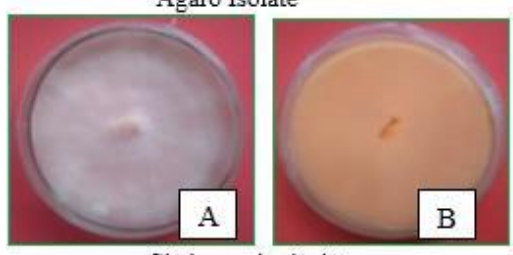

Shebesombo isolate
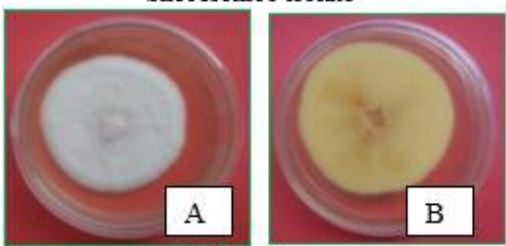

Didu isolate

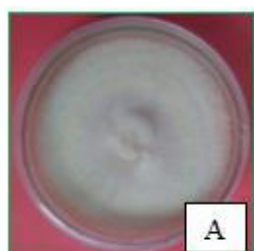

Mettu isolate

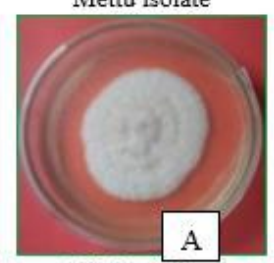

Masha isolate

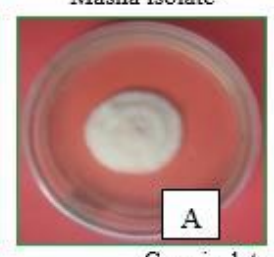

Gera isolate

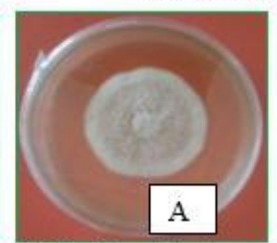

Debubbench isolate

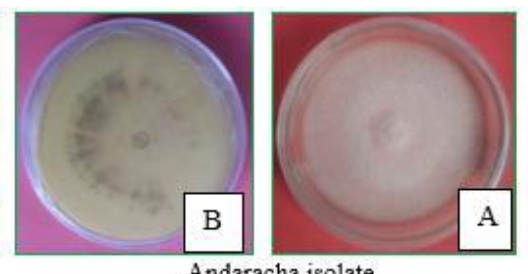

Andaracha isolate
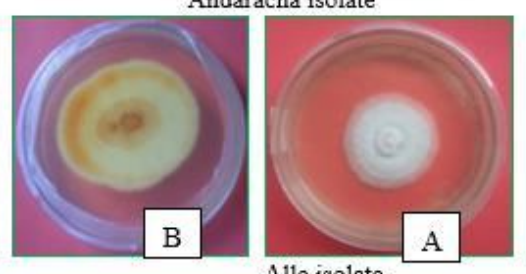

Alle isolate

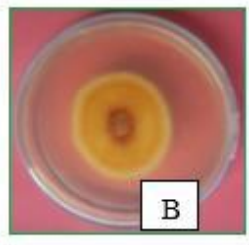

$\mathrm{B}$

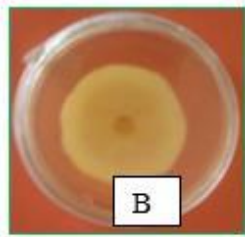

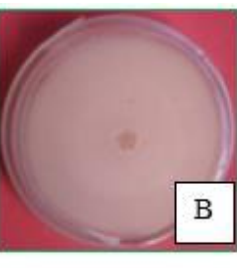

B
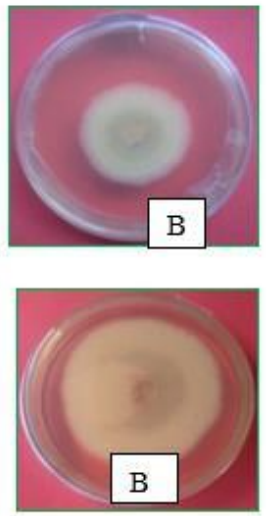

Shako isolate

Figure 3. Colony morphology of $C$. koleroga isolates on PDA at 10 days incubation: A) Front side and B) Back side reverse.

\section{b) Microscopic Identification \\ Hyphae}

Pure culture of C. koleroga showing long, hyaline, wide angled branching mycilia (Figure 4 B) and more or less uniform hyphal width (thickness) measuring 3.75 to $5.00 \mu$ (Figure $4 \mathrm{C}$; Table 3) were observed under microscope.
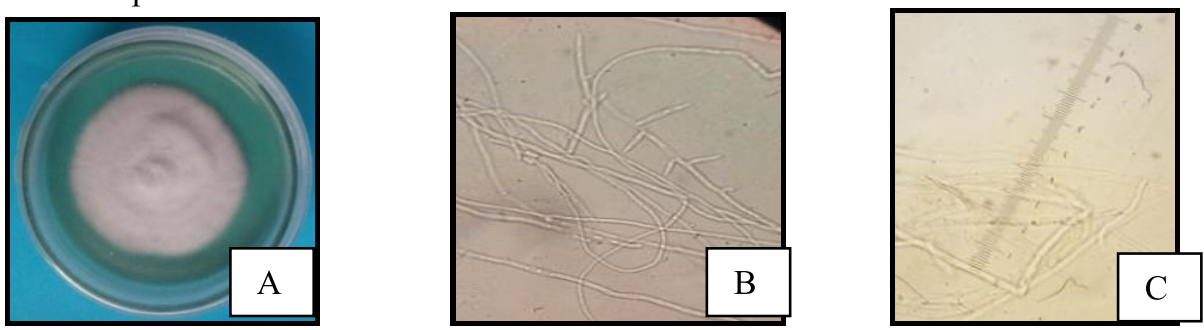

Figure 4. A) Colony morphology of a 7-day-old culture of isolate from Agaro, B) Hyphae of C. koleroga under microscope, C) Hyphal diameter under 40x objective compound microscope of isolate from Agaro.

The texture of the hyphae of $C$. koleroga seemed too filamentous because mostly the mycilia of all the isolates were found in compacted form in groups. Once the pathogen started to produce basidiospores, the basidiospores were found scattered over the surface of the hyphae, which is due probably to the presence of gelatinous materials over the surface of hyphae.

\section{Basidia}

The result of this study indicated that the basidia of Corticium koleroga are ellipsoid to oblong in shape, hyaline in color, not septate, thicker than width of supporting hyphae on which 4-6 basidiospores are directly fixed. It produces the primary basidial cell (probasidium), which is preceded by the final stage of the basidium (metabasidium) and that is collapsed after spore formation (Figure 5). This result is in harmony with previous reports (Burt, 1918; Burt, 1926; Rogers, 1947; Venkataran, 1949). 

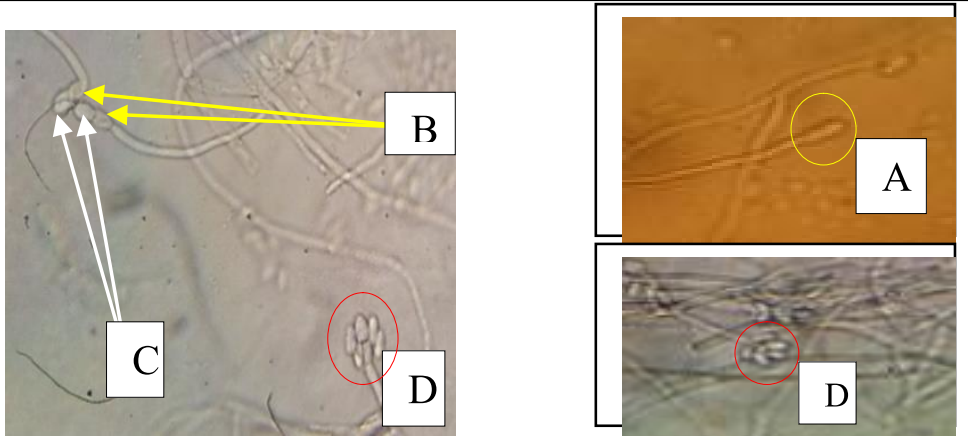

Figure 5. Fruiting body of the fungus C. koleroga:- A) Basidiole B) Probasidia, C) Metabasidia D) Collapsed basidia and basidiospores under compound microscope of 40x objective lens of isolate from Agaro.

\section{Basidiospores}

Basidiospores produced by isolates of C. koleroga collected from different parts of southwestern Ethiopia are fusiform in shape (Figure 6). Statistically there were no significant differences in width of basidiospores among the isolates but there were statistically significant difference $(p \leq 0.05)$ among the isolates in spore length. The length and width of basidiospores varied from 10 to $13.75 \mu \times 3.75$ to $5 \mu$, respectively. Basidiospores of $C$. koleroga appeared as smooth, hyaline, narrow and fusiform in shape measuring 10 to $13.75 \mu \times 3.75$ to $5 \mu$ in size (Table 6; 8).

Table 8. Morphological characteristics of Corticium koleroga isolates collected from some districts of southwestern Ethiopia in 2017 cropping season.

\begin{tabular}{|c|c|c|c|c|c|c|c|}
\hline \multirow[t]{2}{*}{ Isolates } & \multicolumn{4}{|l|}{ Basidia } & \multicolumn{3}{|c|}{ Basidiospore } \\
\hline & Probasidia & $\begin{array}{l}\text { Meta- } \\
\text { basidia }\end{array}$ & Colour & Shape & Colour & Shape & Septa \\
\hline Mettu & + & + & Hyaline & Oblong & Hyaline & Fusiform & - \\
\hline Alle & + & + & Hyaline & Oblong & Hyaline & Fusiform & - \\
\hline Yayu & + & + & Hyaline & Ellipsoid & Hyaline & Fusiform & - \\
\hline Gera & + & + & Hyaline & Ellipsoid & Hyaline & Fusiform & - \\
\hline Agaro & + & + & Hyaline & Oblong & Hyaline & Fusiform & - \\
\hline Andaracha & + & + & Hyaline & Oblong & Hyaline & Fusiform & - \\
\hline Masha & + & + & Hyaline & Oblong & Hyaline & Fusiform & - \\
\hline Shako & + & + & Hyaline & Oblong & Hyaline & Fusiform & - \\
\hline Debubbench & + & + & Hyaline & Ellipsoid & Hyaline & Fusiform & - \\
\hline Shebesombo & + & + & Hyaline & Oblong & Hyaline & Fusiform & - \\
\hline Didu & + & + & Hyaline & Ellipsoid & Hyaline & Fusiform & - \\
\hline
\end{tabular}

$+=$ Peresent $-=$ Absent

The basidiospores were found to adhere or cluster frequently in groups of four to six, which would indicate that most probably basidia have six basidiospores (Figure $6 \mathrm{~A}$ ), which agreed with the work of Wakefield (1913) and Hoehnel (1910). The mycilia and basidiospores of $C$. koleroga appeared to be attached together into a layer, so that not a basidiospores or mycilium can be removed from the mass without difficulty (Figure $6 \mathrm{C}$ ) as described by Rogers (1947).

The basidiospores were scattered over the surface of hyphae and seated on it and separated from each other with difficulty. Basidiospores were attached and scattered over the mycelia at irregular intervals on the threads without any visible pedicel (Figure $6 \mathrm{C}$ ). This mode of attachment is obviously imaginary like the device of the gelatinous matrix.
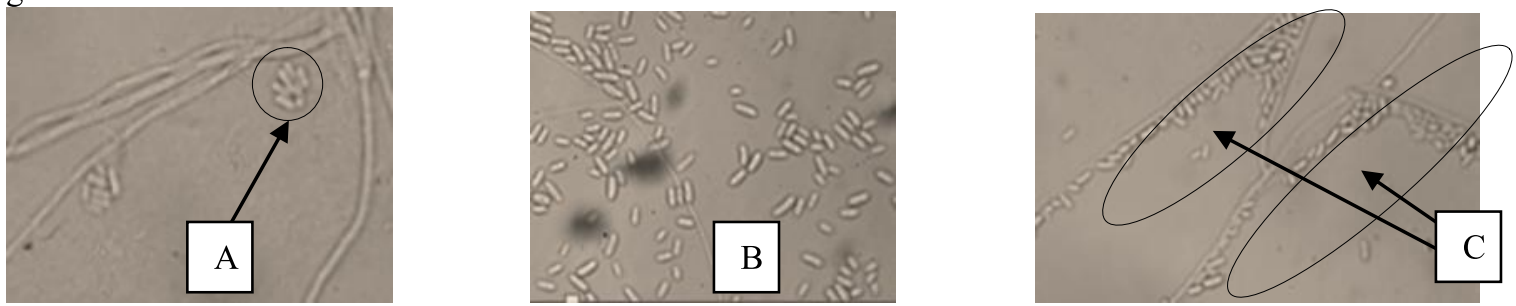

Figure 6. Basidiospores of C. koleroga under compound microscope at 40x magnification. A) A group of six basidiospores, B) Scattered basidiospores, C) Agglutinated mycilia with basidiospores.

\section{Pathogenicity Tests}

The pathogenicity tests with eleven isolates were done on detached leaves and twigs of Coffea arabica 
susceptible variety 74110 . Lesions of thread blight became visible on detached twigs and leaf petioles at the $6^{\text {th }}$ day after inoculation with the C. koleroga isolates from Yayu and Andaracha. The infection sizes were initially small ( $\leq 3 \mathrm{~mm}$ in length), black to ashen strands on twigs and $(\leq 13 \%)$ black leaf petiole later expanded or extended to leaf blade. The necrotic symptoms described earlier were the same as that observed on leaves and twigs of $C$. arabica plants by natural infection in the field, whereas no symptoms developed on the control leaves and twigs (Figures 7,8). Re-isolation of the fungus from symptomatic twig and leaf tissues (inoculated with the isolates) was done on PDA medium. The morphology and cultural characteristics of pure cultures of the re-isolated fungus were the same as that of the original culture of the isolates, fulfilling Koch's postulates.

Longer incubation period of 6 to 10 days was required for symptom development on the detached twigs probably due to non-succulent woody tissue of the coffee twigs and low germination of the basidiospores, whereas relatively shorter incubation period of 5 to 8 days was required for symptoms development on detached leaves because of the availability of the stomata on the leaves in nature (Buller, 1909). The result of the test revealed that both twigs and leaves of coffee can be infected by the $C$. koleroga isolates. There was highly significant difference $(\mathrm{p} \leq 0.01)$ in thread blight lesion size among $C$. koleroga isolates in detached twig and leaf inoculation tests.

All isolates of $C$. koleroga tested in the current experiment were pathogenic and destructive on both Coffea arabica twigs and leaves. Average lesion size on the twigs varied from 52\% by Shebesombo isolate to $94 \%$ by Yayu isolate, when evaluated at 20 days after inoculation (Table 5). On the detached leaves, lesion size ranged between $70 \%$ in Debubbench isolate and $99 \%$ in Yayu isolate at 20 days after inoculation. These current results suggest a slight difference in CTB intensity on the leaves and twigs with the former being more susceptible than the latter.
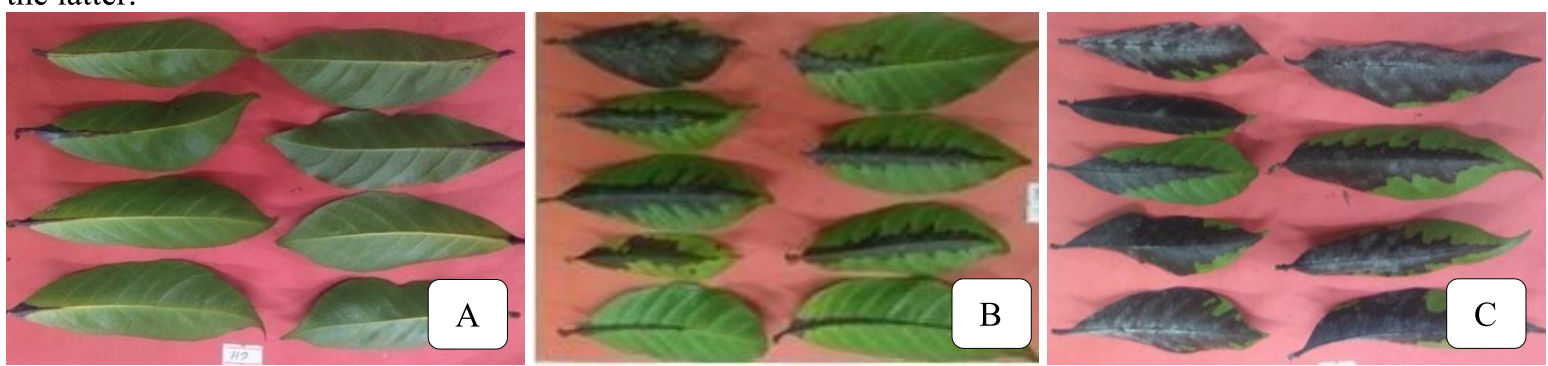

Figure 7. Pathogencity symptom on A) Water sprayed 20 days after sprayed B) Andaracha isolate inoculated on leaf 10 days after inoculation (DAI) C) Andaracha isolate inoculated on leaf 20 DAI.
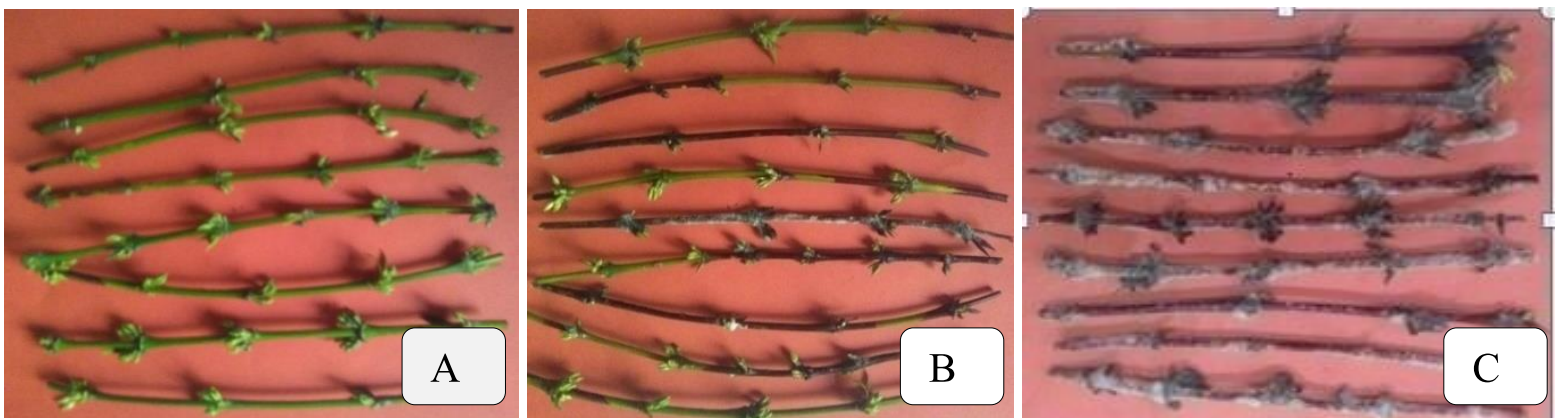

Figure 8. Pathogencity symptoms on A) Water sprayed 20 days after sprayed on twigs B) Yayu isolate inoculated on twigs 10 DAI C) Yayu isolate inoculated on twigs 20 DAI. 
Table 9. Severity of thread blight on coffee plant parts inoculated with C. koleroga isolates collected from 11 districts of southwestern Ethiopia in 2017 cropping season.

\begin{tabular}{lll}
\hline Isolates & Lesion size on twig (\%)* & Lesion size on leaf (\%)* \\
\hline Yayu & $94.43^{\mathrm{a}}$ & $96.67^{\mathrm{a}}$ \\
Mettu & $91.33^{\mathrm{a}}$ & $95.25^{\mathrm{ab}}$ \\
Andarach & $90.48^{\mathrm{ab}}$ & $98.50^{\mathrm{a}}$ \\
Masha & $80.45^{\mathrm{abc}}$ & $84.97^{\mathrm{abc}}$ \\
Shako & $77.89^{\mathrm{a}-\mathrm{c}}$ & $78.63^{\mathrm{abc}}$ \\
Shebesombo & $74.12^{\mathrm{b}-\mathrm{d}}$ & $74.18^{\mathrm{bc}}$ \\
Gera & $71.08^{\mathrm{cd}}$ & $74.53^{\mathrm{bc}}$ \\
Debubbench & $70.78^{\mathrm{cd}}$ & $69.50^{\mathrm{c}}$ \\
Didu & $63.78^{\mathrm{c}-\mathrm{e}}$ & $71.83^{\mathrm{c}}$ \\
Alle & $60.55^{\mathrm{de}}$ & $71.00^{\mathrm{c}}$ \\
Agaro & $51.65^{\mathrm{de}}$ & $71.07^{\mathrm{c}}$ \\
Control & $0.00^{\mathrm{e}}$ & $0.00^{\mathrm{d}}$ \\
\hline LSD (0.05) & $\mathbf{1 5 . 3 3}$ & $\mathbf{9 . 1 9}$ \\
CV (\%) & $\mathbf{8 . 1 7}$ & $\mathbf{9 . 8 9}$ \\
\hline
\end{tabular}

$*=$ Average of three replications.

These tests also revealed that Yayu and Andaracha isolates of Corticium koleroga, were more aggressive on both twigs and leaves than other $C$. koleroga isolates collected from different locations. Both areas represent midlands.

\section{Discussions}

Thread blight of coffee was prevalent in Southwest Ethiopia (Figure 2 and Table 3). It attacks all coffee plant parts except roots and reducing the yield, quality and marketability. Thread blight disease on C. arabica in Ethiopia was known for more than 43 years and considered as minor coffee disease. It sporadically occurred every five to six years between June and September as minor and locally important before 2012 but it gradually became serious and widely observed at midland and highland coffee growing areas of Ethiopia around Gera, Mettu and Limmu coffee plantations and appeared as an epidemic in 2014 (Kifle et al., 2015).

The first recorded thread blight disease outbreak on C. arabica occurred in 2008 at Limmu coffee plantation farm of Gumer with mean disease incidence and severity of $49.2 \%$ and 9.8\%, respectively (Kifle et al., 2015). Other CTB outbreaks were recorded at South-western, western and southern parts of Ethiopia in 2014 with mean incidence and severity of 58.4 and $32.6 \%$, respectively (Kifle et al., 2015). Since then the disease is recurring every year and spreading to the neighbouring zones of coffee producing areas of Ethiopia.

The greater or lesser intensity of the disease is linked to several factors related to the environment, pathogen, host and human activities. Over-exposure of coffee farms to sunlight, difficult adaptation of certain genotypes may also increase the intensity of the disease. In the current study, careful observations at Masha district (Yepho and Abelo peasant associations), Andaracha district (Duyina coffee farms) and Mettu district (Geyi and Ehudgeba peasant associations) revealed that most of the coffee plantation farms representing high CTB disease incidence and severity were cultivated under low shade to open sun, indicating open sun and low shade are conduciveness for the growth and development of CTB disease.

The coffee trees cultivated under medium to high strata of forest and agro-forestry trees, like in the case of Shako district (Berhane kontir forest, Shimmi peasant associations), Shebesombo district (Anjagembo and Sabakawala peasant associations) and Yayu district (Yayu forest) had nil to very low CTB disease incidence and severity, strongly confirming the role of shading in preventing/reducing the CTB disease. This is also supported by Muller et al. (2004), which reported that some coffee fungal diseases like coffee blight (Phoma costarricencis) can be reduced by establishing windbreaks and shade trees because of the fact that trees intercept winds, particularly cold winds and protect coffee parts from mechanical injuries, which otherwise enable the pathogen to penetrate. Vaast et al. (2006) reported that tree shade creates microclimatic conditions that helped to reduce fruit load, which might have led to a shift in the period of coffee tree susceptibility in relation to high disease pressure. Mouen-Bedimo et al. (2008) also suggested that shade can affect and modify certain rainfall characteristics, which might influence pathogen dispersal.

The intensity of CTB in plantation and garden production systems was the highest of all, due to the fact that the coffee farms are slashed frequently for weed control and exposed to soil erosion whereas low human interference in forest and semi-forest coffee production systems could attribute to the relatively reduced disease intensity. Human beings have a considerable role in transmitting disease causing pathogens from diseased plant part to unaffected plant part or from diseased plant to unaffected plant or from affected farm to unaffected coffee farms. Bieysse et al. (2008) noted frequent human interference hastened the spatial and temporal dispersal of 
fungal pathogens.

The basic keys for identification of Corticium koleroga were growth rate, colony on PDA, hyphae, basidial and basidiospore features (Talbot, 1954). On the basis of macroscopic and microscopic characters, the thread blight-causing fungus was identified as Corticium koleroga.

In his description of C. koleroga, Cooke (1876) did not clearly see the perfect state and gave the name Pellicularia to the imperfect state, that is, to the vegetative hyphae, which was later rejected by Venkataran (1949). However, Rogers (1947) previously reported that C. koleroga was characterized by basidia, which are not septate, do not possess stout, swollen sterigmata and that produce basidiospores and germinate directly to form a mycelium. The same author had given a clear account on basidia of $C$. koleroga, terming them apobasidia with the definition of an apobasidium as a basidium whose basidiospores are not apiculate. The same author grouped $C$. koleroga under a group of Homobasidiomycetes other than a Heterobasidiomycete.

Burt (1926) concluded that the cell walls of the hyphae of the C. koleroga are gelatinous in nature. The texture is physical character of C. koleroga, which can be modified with chemicals, age, thickness and moistness of the pathogen (Talbot 1954). Currently, the characteristics of the thread blight-causing pathogen isolated from the C. arabica in Ethiopia are quite similar with the original pathogen re-described by Von Hoehnel (1910) from coffee twigs.

\section{Conclusions}

Coffea arabica is prone to thread blight disease that attacks coffee tree and reduce yield and marketability. CTB disease is becoming an important disease in coffee producing areas of Ethiopia. The disease intensity varied across the surveyed regions, zones and districts. The average thread blight incidence varied from 0 to $46 \%$ while mean disease severity ranged from 0 to $44 \%$ across the surveyed districts. The highest mean disease incidence $(46 \%)$ and severity (44\%) was recorded at Masha followed by Mettu with mean DI (42\%), DS (40\%). On the other hand, the disease intensity was absent in Debubbench, Yaki and Gurafarda districts.

Cumulative rainfall, relative humidity, mean temperature, altitude, coffee production system, shade levels and types have considerable impact on the intensity of thread blight. Increased level of rain fall and relative humidity were associated with an increased risk of thread blight disease development on C. arabica. Besides, disease intensity was the highest at midland and highland altitudes, plantation coffee production systems, open shade level and local coffee varieties.

Based on signs and symptoms on coffee tree, cultural and morphological characters the identity of the pathogen was confirmed to be Corticium koleroga. C. koleroga isolates had cultural colony colour ranging from white to floral white, with filiform to entire margins, growth rate ranged 6 to $9 \mathrm{~mm} /$ day, hyphal width ranged $3.75 \mu$ to $5 \mu$, basidiospore size ranged from 10 to $13.75 \mu \times 3.75$ to $5 \mu$. All $C$. koleroga isolates tested for pathogenicity were pathogenic to coffee twigs and leaves with different aggressiveness.

\section{The Way Forward}

Since the present status of thread blight is remarkably on increasing trend, it is recommended to:-

1. Carry out successive surveys of thread blight disease in all coffee growing areas across the country to have a complete picture on the importance of the disease across coffee agro-ecologies.

2. Further investigate the impacts of weather variables and other factors on thread blight intensity under different agro-ecological conditions in multi-location and multiyear trials to come up with conclusive results.

3. Identify the pathogen associated with thread blight disease by molecular means to confidentially confirm the pathogen.

4. Enhance location based evaluation of coffee genotypes both at field and greenhouse to develop thread blight resistant coffee varieties.

5. Study safe, effective and environmentally friendly disease management options such as cultural practices, biological control, fungicides and integrated disease management.

\section{Acknowledgments}

The authors would like to thank Ethiopian Institute of Agricultural Research (EIAR) for the financial support. Special thanks also go to Jimma Agricultural Research Centre (JARC) and Mettu Agricultural Research subCentre (MARsC) for facilitating logistical support.

The authors also acknowledge the colleagues at JARC especially Mr. Legese H., Mr. Minda T., Mr. Ibrahim A., Mr. Belay A., Mr. Gemechu Asefa, Mr. Dawit M, Miss. Yeshi Siraj, Mr. Dereje and MARsC especially Mr. Selemon A., Miss. Mitike K., Mr. Tesfaye B., Mr. Gemechu F. and Mr. Getachew A. for their helpful suggestions and technical support during the study. 


\section{References}

Bieysse D, Cilas C, Mouen J, Musoli P, Avelino J. (2008). Coffee Disease Risk Analysis: How Epidemiology Knowledge Could Help In Assessing and Preventing Disease Invasion. Proceedings of $22^{\text {nd }}$ International Conference on Coffee Science, pp. 1422-1423.

Buller R. (1909). Spore Deposits the Number of Spores. Researches on Fungi. 1: 79-88.

Burt A. (1918). Corticium Causing Pellicularia Disease of the Coffee, Hypochnose of Pomaceous Fruits, Rhizoctonia Disease. Annual Molecular Botanical Garden. 5: 119-132.

Burt A. (1926). Thelephoraceae of North American Corticium. Annual Molecular Botanical Garden. 13: 173354.

Cavalcante M, Sales F. (2001). Ocorr ência da queima-do-fio (P. koleroga) Emcafezaisem Rio Branco. Empresa Brasileira de Pesquisa Agropecuaria-Embrapa Acre, Rio Branco.

Cooke C. (1876). Some Indian Fungi Pellicularia and Affinities of Pellicularia. Grevillea. 4: 134-135.

CSA (Central Statistical Agency). (2019). Agricultural Sample Survey for The 2018/2019 Crop Season. Volume I Report on Area and Production of Major Crops Private Peasant Holdings, Meher Season. Statistical Bulletin, FDRE/CSA, Addis Ababa, Ethiopia.

Demelash T, Ashenafi A. (2017). Assessment of Commercially Grown Coffee Types for Their Tolerance to Bacterial Blight of Coffee at Sidama and Gedeo Zones, Southern Ethiopia. Sky Journal of Agricultural Research. 6: 001-005.

Eshetu D. Teame G, Girma, A. (2000). Significance of Minor Diseases of Coffea arabica L. in Ethiopia: A Review. in: Proceedings of the Workshop on Control of Coffee Berry Disease (CBD) in Ethiopia. 13 - 15 August 1999, Addis Ababa, Ethiopia. Pp. 58 - 65.

FAS (Foreign Agricultural Service/USDA). (2018). Coffee: World Markets and Trade. Available on: http://www.fas.usda.gov/data/coffee-world-markets-and-trade accessed on June, 2018.

Fernie L. (1970). Improvement of Arabica Coffee in East Africa. In: Leakey (ed) Crop Improvement in East Africa. Billing and Sons Limited, Guildford and London. pp 231-249.

Girma A, Chala J, Arega Z, Abraham T. (2009). Advances in Coffee Diseases Research in Ethiopia. Abraham Tadesse(ed.) (2009) Increasing Crop Production Through Improved Plant Protection - Volume II. Plant Protection Society of Ethiopia (PPSE). EIAR, Addis Ababa, Ethiopia. 542 pp.

Green B, Salkind J. (2016). Using SPSS for Windows and Macintosh, Books Carte. Pearson.

Hoehnel V. (1910). Fragmente zur Mykologie. Mitteilung. 10: 468-526.

Kifle B, Demelash T, Legesse H. (2015). Coffee Thread Blight (Corticium koleroga): a Coming Threat for Ethiopian Coffee Production. J. Plant Pathol. Microb. 6:303-308.

Matovu J, Kangire A, Phiri A, Hakiza J, Kagezi H, Musoli C. (2013). Ecological Factors Influencing Intensity of Coffee Leaf Rust and Coffee Berry Disease in Major Arabica Coffee Growing areas of Uganda. Uganda J. Agric. Sci. 14: 87-100.

Mouen-Bedimo A, Njiayouom I, Bieysse D, Nkeng N, Cilas C, Notteghem L. (2008). Effect of Shade on Coffea arabica Berry Disease Development: Toward an Agro forestry System to Reduce Disease Impact. Phytopathology. 98: 320-325.

Muller A, Berry D, Avelino J, Bieysse D. (2004). Coffee Diseases. Wintgens, N. (Ed.), Coffee: Growing, Processing, Sustainable Production: A Guidebook for Growers, Processors, Traders, and Researchers, pp.491-545.

Musoli P, Cubry P, Aluka P, Billot C, Dufour M, Bellis T, Pot D, Bieysse D, Charrier A, Leroy T. (2009). Genetic Differentiation of Wild and Cultivated Populations: Diversity of Coffea canephora Pierre in Uganda. Genome.52: 634-646.

Ratnadass A, Fernandes P, Avelino J, Habib R, (2011). Plant Species Diversity for Sustainable Management of Crop Pests and Diseases. Agro ecosystems: A Review. Agron. Sustain. Dev. 32: 273-303.

Rogers D. (1947). A new gymnocarpous heterobasidiomycete with gasteromycetous basidia. Mycologia. 39: 556-564.

Rowhani A, Uyemoto J, Golino D, Martelli G. (2005). Pathogen Testing and Certification of Vitis and Prunus Species. Annu. Rev. Phytopathol. 43: 261-278.

SAS (Statistical Analysis System) Software. (2012). Version 9.3, SAS Institute, Cary, NC, USA.

Schneider T (2001). Analysis of Incomplete Climate Data: Estimation of Mean Values and Covariance Matrices and Imputation of Missing Values. Climate. 14: 853-871.

Soto-Pinto L, Romero-Alvarado Y, Caballero-Nieto J, Warnholtz S. (2001). Woody Plant Diversity and Structure of Shade Grown Coffee Plantations in Northern Chiapas, Mexico. Rev. De Bio. Trop. 49: 977-987.

Staver C, Guharay F, Monterroso D. (2001). Designing Pest-Suppressive Multi Strata Perennial Crop Systems: Shade-Grown Coffee in Central America. Agrofor. Sys. 53: 151-170.

Tadesse E, Tesfu K. (2015). Effect of Weed Management Methods on Yield and Physical Quality of Coffee at Gera, Jimma Zones, Southwest Ethiopia. Journal of Resources Development and Management Vol. 11. 
Talbot P. (1954). Micro Morphology of the Lower Hymenomycetes. Bothnlia 6: 249-299.

Tamiru S, Sisay K, Belay A, Demelash T. (2017). Paper Presented to Crop Research Completed Activity Forum 9-14 ${ }^{\text {th }}$ October, 2017. Addis Abeba, in Press.

Than P, Jeewon R, Hyde D, Pongsupasamit S, Mongkolporn O, Taylor J. (2008). Characterization and Pathogenicity of Colletotrichum Species Associated with Anthracnose on Chilli (Capsicum spp.) in Thailand. Plant Pathology. 57: 562-572.

Vaast P, Bertrand B, Perriot J, Guyot B, Genard M. (2006). Fruit Thinning and Shade Improve Bean Characteristics and Beverage Quality of Coffee (Coffea arabica L.) Under Optimal Conditions. J. Sci. Food Agric. 86: 197-204.

Venkatarayan S. (1949). The validity of the Name Pellicularia koleroga Cooke. Indian Phytopathology 2: 186189.

Wakefield G. (1913) Differential Characters in Some Resupinate Hymenomycetes. Plant Diseases of International Importance. 4: 113-120.

Wheeler B.1969. An Introduction to Plant Disease. John Wiley Sons Ltd., London, pp. 301. 244.

Zadoks C, Schein D. (1979). Epidemiology and Plant Disease Management. Oxford University Press, Oxford, $\mathrm{UK}, 427 \mathrm{p}$

Zhu G, Yu Z, Gui Y, Liu Z. (2008). A Novel Technique for Isolating Orchid Mycorrhizal Fungi. Fungal Divers, 33(12), p.123. 